NBER WORKING PAPER SERIES

\title{
THE WELFARE COST OF DISTORTIONS IN THE UNITED STATES TAX SYSTEM: A GENERAL EQUILIBRIUM APPROACH
}

\author{
Charles L. Ballard
}

John B. Shoven

John Whalley

Working Paper No. 1043

\section{NATIONAL BUREAU OF ECONOMIC RESEARCH 1050 Massachusetts Avenue Cambridge MA 02138}

\section{December 1982}

\footnotetext{
This paper was presented at the Third Latin American Meeting of the Econometric Society, Mexico City, July 19-22, 1982, and at the National Bureau of Economic Research, August 11 and 17, 1982. We wish to thank Don Fullerton, Joel Slemrod, and Charles Stuart for helpful comments. The research reported here is part of the NBER's research program in Taxation. Any opinions expressed are those of the authors and not those of the National Bureau of Economic Research.
} 


\section{Abstract \\ THE WELFARE COST OF DISTORTIONS IN THE \\ UNITED STATES TAX SYSTEM: A GENERAL \\ EQUILIBRIUM APPROACH}

Using a general equilibrium model of the United States economy, we examine the combined welfare cost of all taxes in the U.S. revenue system. We find that the welfare losses caused by distortionary taxation can be very large, both on average and at the margin.

The marginal welfare loss to consumers from raising an additional

dollar of revenue is in the range of 34 cents to 48 cents; depending on certain elasticities. This has very important implications for cost-benefit analysis. If a public project must be financed by distortionary taxes which cause deadweight loss, this excess burden must be taken into account when we decide whether to undertake the project. Our calculations indicate that the marginal deadweight loss is between one-third and one-half of marginal revenues. This large wedge could cause us to approve many fewer projects than we would approve if we were to use the simple condition that the sum of the marginal rates of substitution should equal the marginal rate of transformation.

The average deadweight loss per dollar of revenue is smaller than the marginal deadweight loss, but it is still substantial. We estimate that the present value of the gain from replacing the distortionary tax system with certain lump sum taxes would be in the range of $\$ 1.8$ trillion to $\$ 3.1$ trillion, or 13 cents to 22 cents per dollar of revenue. The gains would be about 60 percent as great if the existing system were replaced with a proportional income tax. Replacing the existing system with a consumption-type value-added tax would give even greater gains than those from switching to a proportional income tax.

Charles Ballard Department of Economics Stanford University Stanford, CA 94305
John B. Shoven Department of Economics Stanford University Stanford, CA 94305 (415) 497-3273
John Whalley Department of Economics Univ. of Western Ontario London, Ontario Canada N6A 5 C2 (519) 679-3973 
THE WELFARE COST OF DISTORTIONS IN THE

UNITED STATES TAX SYSTEM: A GENFRAL

EQUILIBRIUM APPROACH

"Every tax ought to be so contrived as both to take out and keep out of the pockets of the people as little as possible over and above what it brings into the public treasury of the state."

$$
\text { Adam Smith - The Wealth of Nations }
$$

\section{Introduction}

In his famous 1776 publication, Adam Smith examined the possibility that the private costs of government revenue are substantially greater than the tax proceeds. He attributed this excess private burden to compliance costs, the distortion of economic activity, and administrative overhead. In this paper, we make a numerical assessment of the second of these costs. In the past, estimates of the efficiency costs of taxation have concentrated on particular aspects of the tax code. Here, we examine the combined welfare cost of all taxes in the United States.

We present two main sets of results. The first set includes calculations of the marginal excess burden of distortionary taxes. When the government collects an additional dollar of revenue, the cost to the private sector exceeds a dollar by the marginal excess burden. This has obvious. implications for cost-benefit analysis. The greater the marginal excess burden, the fewer will be the number of public projects which society ought to approve. We find that the marginal excess burden is quite substantial. The welfare loss from a one percent increase in all distortionary tax rates is in the range of 34 cents to 48 cents per dollar of extra revenue, depending on certain elasticity assumptions. This means that a public project which 
requires a dollar of tax revenue must produce benefits of more than \$1.34. We also calculate the marginal excess burden from increases in various parts of the tax system. Capital taxes (such as corporate and property taxes) and personal income taxes have large marginal excess burdens, while labor taxes (such as the Social Security payroll tax) are less distortionary.

The second set of results includes calculations of the average welfare gain from replacing all or part of the distortionary tax system with some alternative tax. If all distortionary taxes were replaced with a set of lump sum levies, the present value of the welfare gain is in the range of $\$ 1.78$ trillion to $\$ 3.11$ trillion, in 1973 dollars, 1,2 depending on our elasticity values. The annual value of these efficiency costs is from 13 to 22 percent of revenues raised. Thus, average welfare costs are roughly one-half of marginal costs. We also consider replacement of different parts of the tax system with lump sum taxes. Once again, the most distorionary taxes are those which fall on capital and personal income, while the labor taxes are less distortionary. ${ }^{3}$

Obviously, replacing the existing tax system with lump sum taxes is not a realistic policy option. However, we have also experimented with replacing the existing tax system with broadly based but still distortionary taxes. If the only tax were a progressive income tax, more than one-fourth of the welfare loss could be eliminated. If the only tax were a proportional income tax, about three-fifths could be eliminated. ${ }^{4}$

Our calculations suggest that the economic efficiency of the tax system is very important. If the welfare costs of distortionary taxes are this large, then it is difficult to accept the view that microeconomic issues 
are of secondary importance compared to macroeconomic ones. Our results indicate that Harberger triangles may not be nearly as small as Harberger (1964) himself believed them to be. Moreover, as taxes are increased, the deadweight loss triangles grow roughly 34 to 48 percent as much as the revenue rectangles.

In Section II, we discuss some conceptual issues in the evaluation of the welfare cost of tax distortions. In Section III, we discuss the types of distortion generated by various U.S. taxes, and we describe our general equilibrium model. We give special attention to the specification of those elasticity parameters which are of central importance to our results. We present our results in Section IV. Section $V$ is a brief concluding section. 


\section{Evaluating the Cost of Distortions}

The marginal cost of distortionary taxes can be examined with a simple partial equilibrium model. Consider the case of a single good with a downward-sloping compensated demand function and a perfectly elastic supply function, as shown in Figure 1. A proportional tax at rate $t$ shifts the supply function from $P$ to $P(1+t)$ and this, in turn, reduces the quantity consumed.

The welfare loss to the economy from such a tax in partial equilibrium terms is given by the consumer surplus triangle, $A B C$. If we assume that the demand curve is linear, as we have done in Figure 1, the well-known formula for the welfare loss, $\mathrm{L}$, is:

$$
\mathrm{L}=\frac{1}{2} \varepsilon \mathrm{pqt} \mathrm{t}^{2}
$$

where $\varepsilon$ is the compensated price elasticity of demand, and $p$ and $q$ are the initial price and quantity. ${ }^{5}$ As a first approximation, the revenue raised, $R$, is pqt. Thus, the welfare loss per dollar raised is given by

$$
\frac{L}{R}=\frac{\frac{1}{2} \varepsilon p q t^{2}}{p q t}=\frac{1}{2} \varepsilon t .
$$

This average welfare loss is simply the ratio of the area of triangle $A B C$ to rectangle BCGF in Figure 1.

The marginal welfare cost when taxes are raised from to $t^{\prime}$ is the ratio of the increase in the triangle to the additional revenue raised. Inspection of the figure reveals that, to a close approximation, the incremental excess burden is proportional to the tax rate, $t$. If we differentiate equation (1) with respect to $t$, we find 


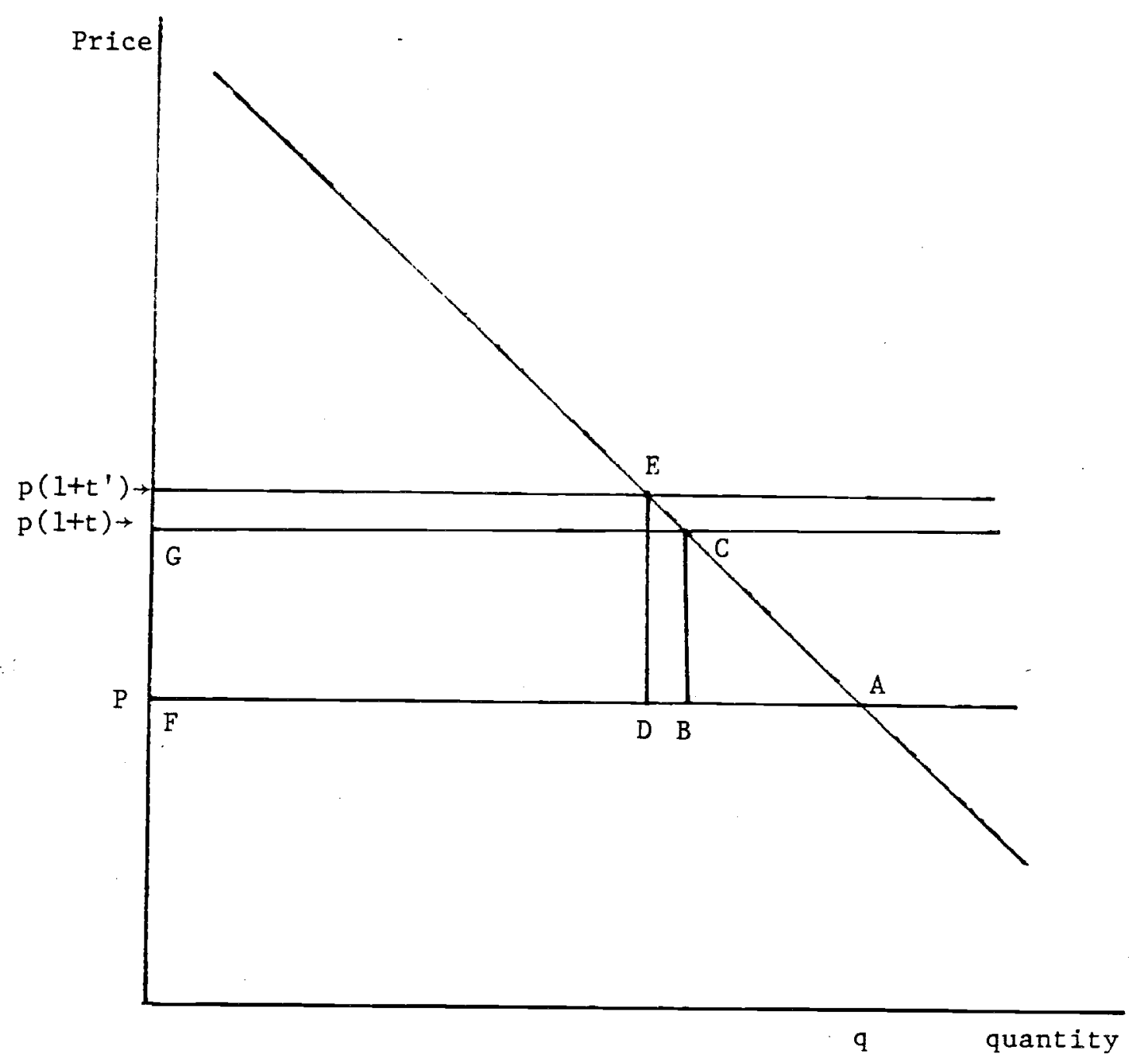

Figure 1--Simple Partial Equilibrium Evaluation of Welfare Cost of a Tax Distortion 
(3)

$$
\mathrm{dL} / \mathrm{dt}=\varepsilon \mathrm{tpq} .
$$

Since revenue is pqt, the marginal revenue is $p q$. Therefore, the marginal excess burden is

(4) $\frac{\text { Marginal Loss }}{\text { Marginal Revenue }}=\varepsilon t$.

The results summarized in the Introduction correspond with this simple partial equilibrium analysis. Comparing equations (2) and (4), we see that the average loss is half the marginal loss. This accords roughly with our range of marginal excess burden from 34 cents to 48 cents and of average excess burden from 13 cents to 22 cents. More importantly, our marginal loss figures seem consistent with the simple partial equilibrium analysis above. We should recognize that the $t$ in equation (4) is the tax rate as a proportion of net expenditure. This means that, for the economy as a whole, the correct figure for $t$ may be around 0.6 or more. ${ }^{6}$ It is difficult to reduce all of the different elasticities to a single elasticity figure for the entire economy. If we could do so, it seems likely that the correct figure would be between 0.5 and 1.0. Multiplying these figures together, as in equation (4), would give us a figure for marginal excess burden in the same region in which our actual calculations lie.

We do not mean to suggest that the only standard for judging our results is their consonance with partial equilibrium results. The general equilibrium approach has many advantages. It enables us to consider simultaneously many tax changes in many sectors and it does not rely on local approximations. Still, we find it encouraging that a simple partial equilibrium analysis lends support to our conclusion that welfare costs can be very large, both on average and on the margin. 
Our actual welfare calculations are more complicated than those suggested by equation (1), for two reasons. First, we have a large model with many different goods and tax rates which vary widely. It can be shown that efficiency loss estimates increase with additional disaggregation (see Fullerton, Henderson, Shoven [1983]). Further, in this paper we find that the variance in tax rates adds substantially to the deadweight losses. Second, we consider the economy's evolution over time explicitly, by calculating a sequence of equilibria. We have 12 consumer groups, and for each of them we compute a sequence of values for consumption, leisure, and saving in each period, both in the presence and absence of the tax change. We calculate each consumer's utility in each period from current consumption and leisure. Then we take the present value of these utilities, for the before-change sequence and the after-change sequence. For each consumer, we compute the financial transfer necessary to equate the present values in the absence and presence of the tax change. The sum of these figures across the 12 households is our measure of the dynamic welfare change. This calculation is in the spirit of the static Hicksian equivalent variation. 
III. A General Equilibrium Model of the

U.S. Economy and Tax System: Structure and Data

To keep the focus of this paper on results and policy implications, only a brief overview of model structure is given here. We provide a very detailed description of our model in Chapters 3-7 of Ballard, Fullerton, Shoven, and Whalley (1983).

First, we summarize the production side of the model. In any single period, there are 19 producer good industries that use capital and labor in constant elasticity of substitution (CES) value-added functions. They also use the outputs of other industries through a matrix of fixed input-output coefficients. Tax rates on labor for each industry are derived by taking payroll taxes and other contributions as a proportion of labor income, while tax rates on capital for each industry are derived by taking corporate income, corporate franchise, and property taxes as a proportion of capital income. Each of these 19 producer goods is used directly for investment, for net exports, and by the government. The transformation of producer goods into consumer goods is represented by a matrix of fixed coefficients. This procedure is necessary because the goods classification of consumer expenditure data is different from the classification of the outputs of the 19 production sectors.

On the consumer side of the model, we have 12 consumer groups, which are distinguished by their money income ${ }^{7}$ in 1973 (the basic data year for the model). Each consumer group has an initial endowment of capital and labor. Consumer decisions regarding factor supplies are made jointly with their consumption decisions. Each household at any point in time has a nested CES utility function of the form: 


$$
U=U\left[H\left(\prod_{i=1}^{15} x_{i}^{\lambda i}, \ell\right), C_{f}\right],
$$

where $H$ is the instantaneous utility function defined over current consumption commodities $X_{i}$ and leisure $\ell$, and the function $U$ determines the allocation between current welfare and expected future consumption, $\mathrm{C}_{\mathrm{f}}$. Current consumption commodities $X_{i}$ are aggregated using a Cobb-Douglas function, whereas both $U$ and $H$ are CES functions.

Most of the simulations reported here employ the assumption of myopic expectations. Because of this assumption, the current rate of return and other current prices are all that we require to formulate a budget in terms of prices for present and future consumption. With myopic expectations, the expected price of future consumption depends inversely on the current rate of return, which consumers expect will obtain in all future periods. When $U$ is maximized subject to a budget constraint, we get a desired level of $C_{f}$ for each consumer. The demand for $\mathrm{C}_{f}$ is then translated into a demand for saving in the current period. The latter is, in turn, translated into a vector of investment demands for the 19 industry outputs.

The myopic expectations assumption stands at one extreme along a spectrum of possible assumptions regarding conșumer beliefs about future prices. At the other extreme is the assumption of perfect foresight, under which consumer beliefs about the future turn out to be correct. Ballard and Goulder (1982) have investigated the sensitivity of our model's results to different assumptions about expectations. They define the number of years of foresight as the number of years into the future over which consumers have correct beliefs. When the number of years of foresight is zero, consumers have myopic beliefs. In the limit, as the number of years of foresight grows 
large, we approach perfect foresight. In this paper, we use the algorithm developed by Ballard and Goulder to study the sensitivity of our results to the number of years of foresight. We find that our results are fairly robust with respect to the assumptions on consumer beliefs about future prices. Therefore, most of our calculations are of myopic sequences of equilibria, since these are less expensive to compute.

Government collects taxes from both the production and demand sides of the economy and uses the revenue in a balanced budget. The government purchases producer goods via a Cobb-Douglas utility function, makes direct transfer payments to consumers, and subsidizes government enterprises. A simple trade sector closes the model.

We specify our model with data from 1973 because this is the most recent year during which the Department of Labor conducted a Consumer Expenditure Survey. In addition to this survey, we use four other major data sources. These are the July, 1976, Survey of Current Business, the Bureau of Economic Analysis Input-Output Matrix, unpublished worksheets of the U.S. Department of Commerce National Income Division, and the U.S. Treasury Department's Merged Tax File. In order to use all of these data together, adjustments are made to ensure that each part is consistent with the rest. All data on industry and government uses of factors are accepted as given, while the data on consumer factor incomes and expenditures are correspondingly adjusted. Tax receipts, transfers, and government endowments are accepted as given, and government expenditures are adjusted in order to yield a balanced budget. Similar adjustments ensure that supply equals demand for all goods and factors, and that trade is balanced. 
The fully consistent data set defines a single period benchmark equilibrium in terms of transactions. These observations on values are separated into prices and quantities by assuming that a physical unit of a good or factor is the amount that sells for one dollar. All benchmark equilibrium prices are $\$ 1$, and observed values are the benchmark quantities. The equilibrium conditions of the model are then used to determine the behavioral equation parameters, consistent with the benchmark data set. This procedure calibrates the model to the benchmark data, in the sense that the benchmark data can be reproduced as an equilibrium solution to the model before any policy changes are considered. In order to implement this procedure, we specify the elasticities of substitution between capital and labor in each industry, on the basis of the econometric literature. We also specify labor supply and saving elasticities, to which substitution elasticities in preferences are calibrated. Factor employments by industry are used to derive production function weights, and expenditure data are used to derive utility function weights. This calibration procedure allows for a test of the solution and ensures that the various agents' behaviors are mutually consistent in our benchmark data before we evaluate policy changes.

The elasticities of labor supply and saving are important for our results, so it is appropriate to discuss our choices. There are a large number of estimates for the uncompensated elasticity of labor supply with respect to the real, net-of-tax wage. Elasticity estimates for males are mostly small and negative, ranging from -0.40 to zero. Borjas and Heckman (1978) review these econometric studies and reduce the bounds to -0.19 and -0.07. The estimates for females are more often positive, and can be large in absolute value. Killingsworth (1982) finds that the elasticity estimates for females are mostly between 0.20 and 0.90 in cross-section studies. 
We choose a value of 0.15 for each of our consumer groups, which we take as a weighted average of plausible estimates for males and females. We use this value to select the elasticity of substitution between present consumption and present leisure for the "H" function in equation (5) for each consumer. To test the sensitivity of the model, we also use a zero uncompensated labor supply elasticity.

As we pointed out in Section II, the compenstated elasticities are the really important elasticities, from the point of view of our welfare cost calculations. Even though we specify the labor supply decision in our model on the basis of an uncompensated elasticity, we still can compute the implied compensated elasticities. The basic theory of consumer behavior, Erom which the econometric literature on labor supply derives, implies that the compensated labor supply elasticity should exceed the uncompensated elasticity (i.e., the income effect discourages work). This is borne out by the numbers in Table 1 .

TABLE 1

COMPENSATED LABOR SUPPLY ELASTICITIES

\begin{tabular}{|c|c|c|}
\hline $\begin{array}{c}\text { Consumer } \\
\text { Income Group } \\
\text { (in } 1973 \text { dollars) }\end{array}$ & $\begin{array}{l}\text { Uncompensated } \\
\text { Elasticity }=0.0\end{array}$ & $\begin{array}{l}\text { Uncompensated } \\
\text { Elasticity }=0.25\end{array}$ \\
\hline $0-3,000$ & 0.193 & 0.342 \\
\hline $3,000-4,000$ & 0.236 & 0.385 \\
\hline $4,000-5,000$ & 0.274 & 0.423 \\
\hline $5,000-6,000$ & 0.295 & 0.444 \\
\hline $6,000-7,000$ & 0.311 & 0.460 \\
\hline $7,000-8,000$ & 0.330 & 0.480 \\
\hline $8,000-10,000$ & 0.341 & 0.491 \\
\hline $10,000-12,000$ & 0.344 & 0.495 \\
\hline $12,000-15,000$ & 0.356 & 0.508 \\
\hline $15,000-20,000$ & 0.351 & 0.503 \\
\hline $20,000-25,000$ & 0.341 & 0.495 \\
\hline $25,000+$ & 0.270 & 0.431 \\
\hline
\end{tabular}


The other key parameter is the elasticity of saving with respect to the real, after-tax rate of return. We use the value of this elasticity to choose values for the elasticity of substitution between present consumption, $H$, and future consumption, $-C_{f}$, for each consumer.

There is considerable controversy in the econometric literature regarding the value of the uncompensated saving elasticity. For a long time, the consensus appeared to favor a zero value for this elasticity. This proposition was termed Denison's Law, after Denison (1958). In more recent work, Boskin (1978) has estimated this elasticity to be approximately 0.3 to 0.4. On the other hand, Summers (1981) derives savings elasticities between 1.5 and 3.0 , by manipulating the parameters of a life cycle model. Each of these studies has problems of technique and interpretation. In particular, for reasons outlined in the paper by Starrett (1982), Summers's elasticity figures may be high. We report simulations using the values of 0.0 and 0.4 for the saving elasticity. As is to be expected, the average and marginal excess burdens increase as the saving elasticity increases. If the elasticity were in the range suggested by Summers, the welfare gains from remvoing all distortions would be more than twice as great as those reported here. Another important parameter is the steady-state growth rate of the benchmark equilibrium sequence. To derive this rate, we compare the amount of observed 1973 saving to the capital stock. This gives us a rate of growth of capital, which is 2.89 percent per year. We then assume that the number of effective units of labor grows at the same rate. Though labor endowments grow at this fixed annual rate in both the benchmark sequence and the revised sequence, the demand for leisure is endogenous, which implies that actual labor supply may differ. Though the capital stock grows at this rate in the 
benchmark sequence, endogenous saving implies that capital in the revised case may grow at a different rate.

The 2.89 percent labor growth rate is assumed to be equally divided between Harrod-neutral technical change and population growth. Our welfare measures of tax changes are adjusted to account only for the initial population. If total population were included in the welfare calculations, the importance of future periods would be sensitive to population growth.

A final important parameter is the real net-of-tax return to capital in the benchmark data. Since this value is used to calibrate preference parameters under the assumption of intertemporal utility maximization, it also determines the rate of time preference in the benchmark sequence of equilibria. We use four percent for the average value of this parameter, but each income class receives a net-of-tax return that depends on its own marginal tax rate.

In Table 2, we present a summary of the way in which we model the effects of the various taxes. On the basis of this modeling, we calculate tax rates. Table 3 includes some summary information about these tax rates. The figures in Table 3 suggest that capital taxes should be candidates for being major sources of welfare cost. Defining capital tax rates as a proportion of net income (such that some rates exceed unity), we find that the average tax rate on capital at the industry level is about 0.97 . (Note that we do not incorporate the reduction in capital tax rates which was part of the 1981 Economic Recovery Tax Act. For a study of the effects of these changes, see Fullerton and Henderson [1981].)

In contrast to capital taxes, labor taxes (Social Security and other contributions) raise a large amount of revenue, without rates which are high or widely dispersed. 


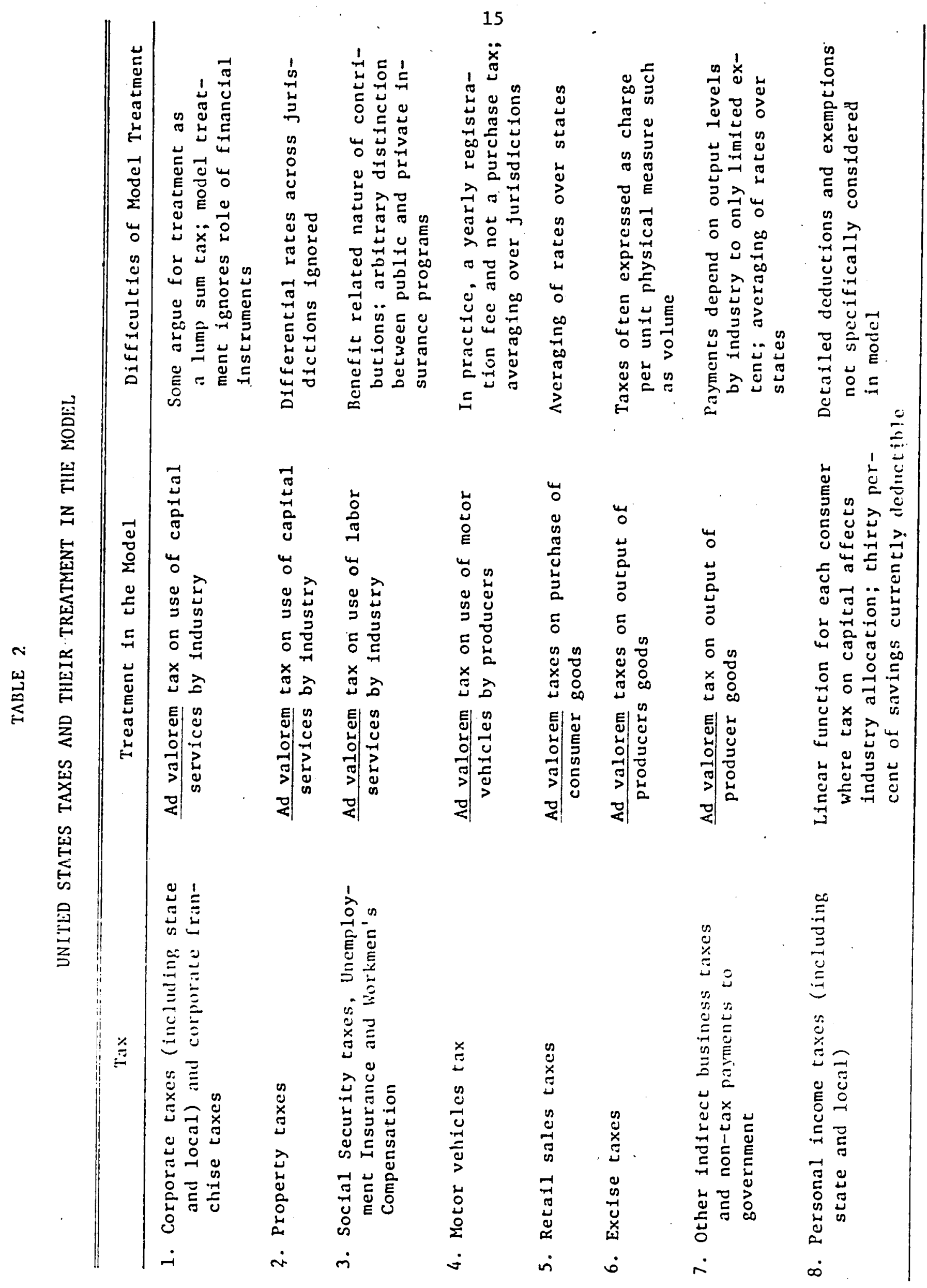




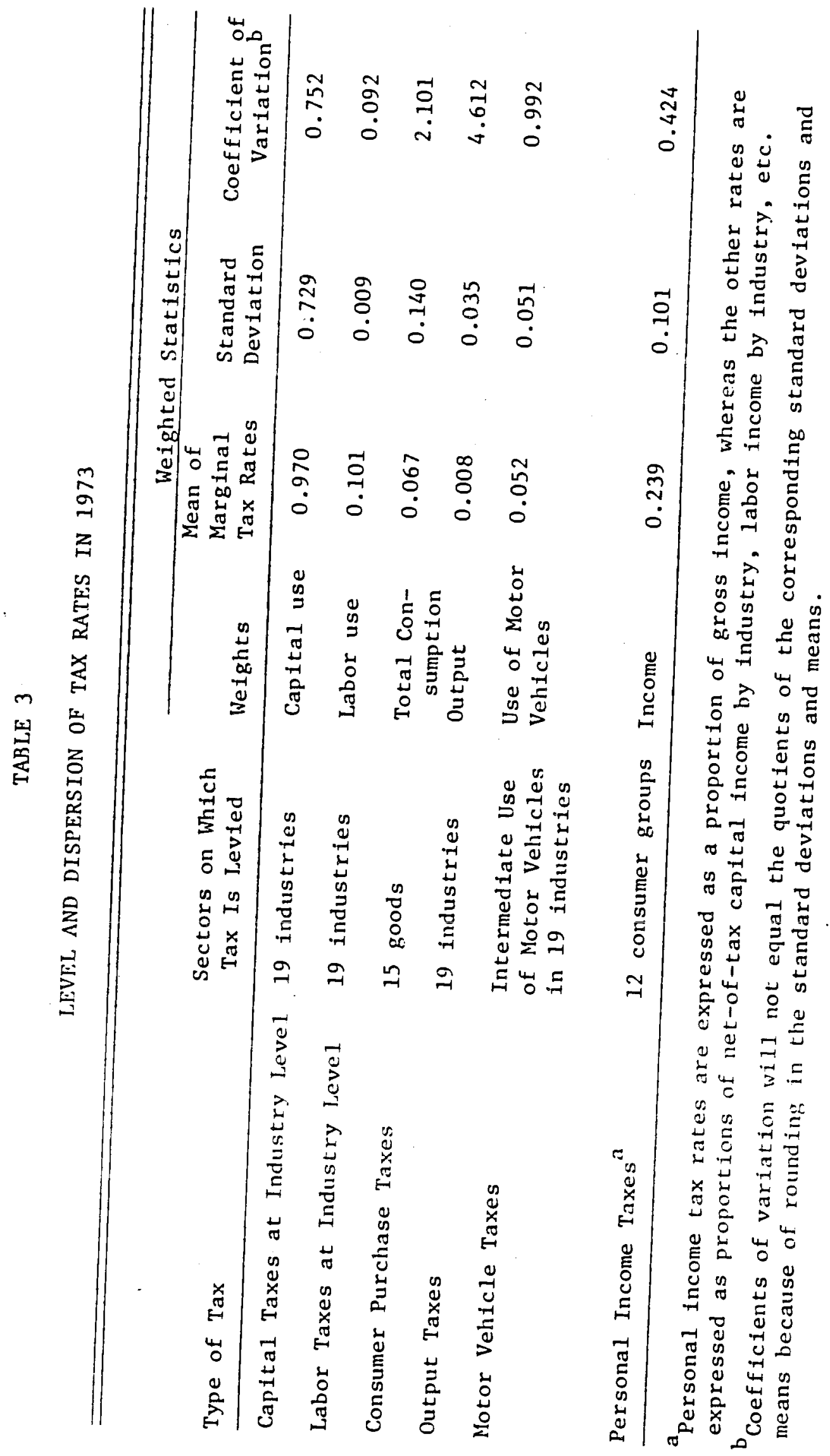


Marginal income tax rates are high, on average. In addition, the income tax rates differ substantially among consumers. In our model, each of the 12 consumer groups faces a linear income tax schedule. The rates rise from 0.01 for the poorest group to 0.41 for the richest.

Consumer sales and excise tax rates average about 6.7 percent, and the rates for most goods are reasonably low. However, there are three notable exceptions. The tax rate on alcoholic beverages is 0.875 , on tobacco; 0.958, and on gasoline and other fuels, 0.295.

The key distortions created by the income tax deal with factor supplies. It is widely recognized that the income tax distorts labor supply decisions. In addition, the supply of new capital through saving is affected by the "double taxation" of saving. Double taxation is mitigated partially by tax shelters (such as Individual Retirement Accounts). We model the U.S. tax system of 1973 by assuming that 30 percent of saving is sheltered in this way.

Another aspect of the effect of the income tax on factor supplies is the fact that consumers with higher incomes face higher marginal tax rates. Since saving is heavily concentrated in the top tail of the income distribution, much of the saving in the economy occurs where the tax rates are highest. 8 On the other hand, labor supply is much more widely diffused. Consequently, the effective rates of tax on labor income are lower, on average, than those facing capital income.

In addition to factor supply decisions, the income tax also has important features which distort choices among industries and commodities. The most prominent of these is the preferential treatment of housing which results from the absence of tax on the imputed income of owner-occupied housing. This is compounded by preferential treatment for capital gains on 
houses. These features of the tax law combine to create substantial static resource allocation and intertemporal distortions.

In modeling the corporate tax, we follow in the tradition of Harberger (1962, 1966) who treats it as a partial factor tax. More recently, this treatment has been the subject of active debate. It has been argued that the corporate tax acts as a tax on the return to equity, rather than on the total return to capital invested in the corporation. Stiglitz (1973) has argued further that if all marginal investments by firms are debt financed, the corporate tax operates as a lump sum tax. However, so many features of corporate financial behavior remain unexplained that we follow Harberger's procedure of treating the corporate tax as an ad valorem tax on capital, with average and marginal rates the same. Thus the corporate tax misallocates capital services among industries in the economy, since tax rates differ by industry. In addition, the tax affects saving decisions, since savers who acquire corporate equity have to pay a higher tax rate on the return to their savings than they would pay in the absence of the tax. Further distortions operate through the treatment of depreciation in the corporate tax. On the other hand, depreciation allowances can be taken at rates which are faster than the true depreciation of assets. On the other hand, depreciation is calculated on a historical cost basis. Capital tax rates also include the investment tax credit. All these features combine to produce a pattern of tax rates by industry which is significantly discriminatory.

Similarly to the corporate tax, we treat the property tax as a differential tax on capital by sector. This falls most heavily on residential housing, but structures in other capital-using industries in the economy are also liable for the tax. As with the corporate income tax, both static and dynamic distortions occur. 
Consumer sales taxes have a variety of effects. Even if the sales tax system covers all commodities evenly, it still distorts labor supply decisions. Additional distortions come from the nontaxation of food and other exempted items. The specific excises on alcohol, tobacco, and gasoline are sharply discriminatory in our model, since we treat them (along with sales taxes) as ad valorem taxes. However, we recognize that this treatment could be challenged. The taxes on alcohol and tobacco could be defended as externality correcting, and the gasoline tax defended as a benefit-related fee for the use of the highway system.

The last major component of the tax system consists of payroll taxes for Social Security, unemployment insurance taxes, and workmen's compensation taxes. We treat these as ad valorem taxes on labor at the industry level, rather than as benefit-related charges, because the correspondence between taxes and benefits for any individual is very rough.

In our discussion of the various types of taxes, we have repeatedly distinguished intertemporal distortions (which affect saving decisions) from intersectoral distortions (which affect choices among industries or consumer goods). Many of the general equilibrium models which exist today can calculate only a single equilibrium. Consequently, they are poorly equipped to analyze the relative importance of intertemporal and intersectoral distortions. Our model calculates a sequence of equilibria, covering an arbitrarily long period of time. The equilibria are tied together by endogenous saving decisions and exogenous growth of labor endowments. This allows us to assess intertemporal distortions as well as intersectoral ones.

Through their interaction, utility-maximizing consumers and profitmaximizing producers are assumed to reach a single period competitive equilibrium 
where all profits are zero and supply equals demand for each good and factor. Starting with data on endowments, tax rates, preferences, and production parameters, we use Merrill's (1972) algorithm, a revised version of Scarf's (1973) algorithm, to calculate prices that satisfy these conditions at each point in time. The algorithm can accommodate any number of sectors and agents. Since this algorithm is not based on differential calculus, the model can handle a number of large distortions and evaluate the effects of simultaneous changes in any of them without linearity assumptions and without ignoring income effects. This allows us to appraise tax policy changes which are of sufficient magnitude to cause interactive effects throughout the economy.

We assume that there is no involuntary unemployment of factors. Markets are perfectly competitive, with no externalities, quantity constraints, or barriers to factor mobility.

For the benchmark sequence of equilibria, we assume that the economy was on a balanced growth path in 1973. The first equilibrium in the sequence replicates the 1973 data. Subsequent equilibria are merely scaled-up versions of the initial equilibrium. Prices remain constant, and all quantities grow at the same rate (the rate of growth of the effective labor force). We then alter tax parameters and calculate a revised sequence of equilibria. Since we compute a complete set of prices and quantities under alternative tax policies, we can estimate the changes in utility or income for each consumer group, changes in national income, and all new factor allocations among industries. Clearly, we cannot calculate an infinite sequence of equilibria. Instead, we calculate equilibria a certain number of years into the future and then calculate a termination term. The welfare evaluation in the termination term will be precisely correct if the economy is on a steady-state growth path, 
as is the case in our base case squence of equilibria. In a revised case sequence, the tax change causes a transition toward a new steady-state growth path. In this case, the termination term calculations will only be approximate, with the accuracy of the approximation becoming better as the economy settles more closely toward the new steady-state growth path. In our calculations of marginal excess burden, the changes in relative prices are small since the tax changes are small. Therefore, a good approximation could be made by beginning the termination term after 50 years or so. However, our calculations of average excess burden involve huge changes in relative prices, so that the approach to the new steady-state takes a very long time. In order to improve the accuracy of the approximation in the termination term, we carry our equilibrium calculations 100 years into the future, by calculating 21 equilibria spaced five years apart. 


\section{Results of Computations}

\section{A. Calculations of Marginal Excess Burden}

The main results of our marginal excess burden calculations are shown in Tables 4 and 5 . All of these results are based on sequences of myopic expectations equilibria. In the case of small policy changes which do not change relative prices a great deal, the structure of expectations makes very little difference. The results presented elsewhere in this paper involve maintaining the same level of spending in the base case and revised sequences, but revenue yield equality is not appropriate when we are interested in the marginal welfare cost of increasing the overall size of the government. Consequently, Tables 4 and 5 contain the only set of results in this paper which were obtained without requiring yield equality. Otherwise, we would be unable to determine the amount of revenue which would be caused by a marginal change in tax rates.

We want to compare the marginal deadweight loss with the net change in the amount of resources which flow from consumers to the government and thus taxes which the government pays to itself are netted out.

Table 4 shows the marginal excess burden from raising all marginal tax rates in the model by one percent. As would be expected, the marginal excess burden is greater when economic activities are more elastic. Nevertheless, the results are fairly robust over a reasonable range of values for the key consumer elasticities.

Our figures for the marginal welfare cost are quite substantial. They indicate that the transfer of an additional dollar to the government causes a deadweight loss of from 34 to 48 extra cents. This means that additional 
TABLE 4

MARGINAL EXCESS BURDEN PER DOLLAR OF MARGINAL REVENUE FOR THE ENTIRE TAX SYSTEM ${ }^{a}$

Marginal Excess

Burden per Dollar

A. Saving elasticity $=0.4$, Labor supply elasticity $=0.15 \quad 48 \mathrm{c}$

B. Saving elasticity $=0.4$, Labor supply elasticity $=0.0 \quad 36 \mathrm{c}$

C. Saving elasticity $=0.0$, Labor supply elasticity $=0.15 \quad 45 \mathrm{c}$

D. Saving elasticity $=0.0$, Labor supply elasticity $=0.0$

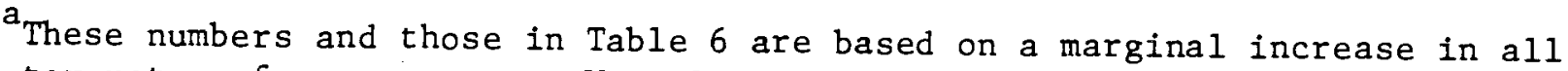
tax rates of one percent. We calculated sequences of 21 equilibria, spaced five years apart (so that the horizon is 100 years). Transfer payemnts to individuals were held constant.

\section{TABLE 5}

MARGINAL EXCESS BURDEN PER DOLLAR OF MARGINAL REVENUE FOR MAJOR GROUPS OF TAX RATES

( saving elasticity $=0.4$, labor supply elasticity $=0.15$ )

Marginal Excess

Burden per Dollar

A. Capital Taxes at the Industry Level

$49 c$

B. Labor Taxes at the Industry Level

$19 c$

C. All Consumer Sales Taxes

$63 \mathrm{c}$

1. Taxes on alcohol, tobacco, and gasoline only $\$ 1.18$

2. Taxes on goods other than alcohol, tobacco, and gasoline.

$35 c$

D. Income Taxes

$55 c$

E. Output Taxes

1. Government enterprises, subsidy rate unchanged $41 c$

2. All 19 rates changed 
public expenditures only ought to be undertaken if their marginal benefits are at least 34 percent greater than the revenues raised. We should be aware that the bucket marked "distortionary taxes," with which we carry resources from the private sector to the public sector, is a leaky bucket indeed.

In Table. 5, we break down the results of Table 4 by calculating the marginal excess burden for the major tax rate subgroups, using a labor supply elasticity of 0.15 and a saving elasticity of $0.4 .^{9}$ These results are not surprising, in view of the data on the level and dispersion of tax rates in Table 3. The high and widely varying tax rates on capital and consumer sales, and the progressive personal income tax rates lead to the greatest losses. This suggests that the figure for the marginal excess burden for the entire tax system could be reduced somewhat by a general equalization of rates.

\section{B. Calculations of Total and Average Welfare}

Costs of Distortionary Taxes

For most of the simulations reported in this section, we remove all taxes, and replace them by lump sum levies in proportion to personal income taxes and sales taxes paid. These are the only two parts of the tax system for which the legal incidence (although not the economic incidence) can be attributed to consumers directly. By assigning the lump sums in this manner, we make a crude attempt to abstract from income effects (which can be important) and concentrate on the efficiency aspects of the tax system.

In Table 6, we report the welfare gain from this tax change for the same values of elasticity parameters which we used in Table 4 . It seems to 
us that these welfare gains are very substantial, even for the case in which both the uncompensated labor supply elasticity and the uncompensated saving elasticity are zero. Even under these fairly inelastic assumptions, the welfare gain from replacing the distortionary taxes exceeds one-eighth of revenues.

In Table 7, we analyze the sensitivity of these results to assumptions about expectations. The number of years of foresight is as defined in section II. Clearly, the expectational assumptions do not alter the basic magnitude of our results. Since the future is discounted at a rate of four percent, price changes in the distant future have little effect on consumer decisions. Also, since prices change more rapidly at first and then approach a new steady-state growth path, the consumer with $T$ years of foresight is alerted to more than half of the price change to which the consumer with $2 \mathrm{~T}$ years of foresight is alerted. For a much fuller discussion of this type of result, see Ballard and Goulder (1982).

In the case of the first simulation in Table 6 , the present value of the welfare gains is $\$ 3,111$ billion in 1973 dollars. This is 9.14 percent of the total present value of population-corrected national income, 6.26 percent of the present value of expanded national income (including the value of leisure), and 22.1 percent of revenues.

Of all the changes in behavior which contribute to this welfare improvement, the most notable are those dealing with saving and the capital stock. Saving is 80 percent higher in the initial equilibrium than it was in the initial period of the base sequence. In addition, saving continues at high levels: saving after 100 years of the revise sequence outstrips the corresponding figure for the base sequence by 70 percent. The continued high 
TABLE 6

WELFARE GAINS FROM REPLACING EXISTING DISTORTIONARY TAXES , WITH LUMP SUM TAXES IN PROPORTION TO INCOME AND SALES TAXES PAID, FOR DIFFERENT ELASTICITIES

\begin{tabular}{cccc}
\hline \hline Saving & $\begin{array}{c}\text { Labor } \\
\text { Supply } \\
\text { Elasticity }\end{array}$ & $\begin{array}{c}\text { Welfare Gain } \\
\text { (in billions of } \\
\text { 1973 dollars) }\end{array}$ & $\begin{array}{c}\text { Gain as } \\
\text { Percentage of } \\
\text { Base Case } \\
\text { Revenues }\end{array}$ \\
\hline 0.4 & 0.15 & $\$ 3,110.7$ & $22.1 \%$ \\
0.4 & 0.0 & $2,497.8$ & 17.7 \\
0.0 & 0.15 & $2,236.1$ & 15.9 \\
0.0 & 0.0 & $1,775.5$ & 12.6 \\
\hline
\end{tabular}

TABLE 7

WELFARE GAINS FROM REPLACING EXISTING DISTORTIONARY TAXES WITH LUMP SUM TAXES, SAVING ELASTICITY $=0.4$, LABOR SUPPLY ELASTICITY $=0.15$, FOR DIFFERENT AMOUNTS OF FORESIGHT ON THE PART OF CONSUMERS

\begin{tabular}{lcc}
\hline \hline $\begin{array}{c}\text { Number } \\
\text { of Years } \\
\text { of Foresight }\end{array}$ & $\begin{array}{c}\text { Welfare Gain } \\
\text { (in billions of } \\
1973 \text { dollars) }\end{array}$ & $\begin{array}{c}\text { Gain as } \\
\text { Percentage of } \\
\text { Revenues }\end{array}$ \\
\hline Myopia & $\$ 3,110.7$ & $22.1 \%$ \\
10 years & $3,061.1$ & 21.7 \\
50 years & $3,039.1$ & $21: 6$ \\
\hline
\end{tabular}


level of saving is the result of two of fetting forces. First, as capital becomes more abundant, its relative price decreases. Since we have a positive saving elasticity, this causes less saving, ceteris paribus. However, the increased capital stock makes the economy wealthier. Given our functional form assumption for the saving decision, this leads to an increase in saving, ceteris paribus. In the 100 years covered by this sequence of equilibria, the capital/labor ratio increases by 31 percent. As we said, this simulation involves large movements in relative factor prices. The path for the price of capital relative to the price of labor is shown in Table 8 , for the myopic simulation we have been considering, and for the simulations with foresight. In the first equilibrium, the price of capital relative to the price of labor rises from 1.0 in the base case to 2.129 in the revise case, under all formulations of expectations. (Recall that prices are defined as net of taxes.) The change in the first period is the same for all formulations of expectations because the extra saving does not augment the capital stock until after the first equilibrium is complete. Capital deepening then causes the price to fall, steeply at first and less steeply later on as the economy approaches its new steadystate growth path. When consumers have foresight, they recognize that the price of capital will fall, so that saving becomes less attractive. They save slightly less, and the price of capital falls less steeply.

From Table 8 , it is clear that the economy has come fairly close to its new steady-state growth path within 100 years. This time path of capital prices implies that in the short run capital taxes are borne by capital, as suggested by Harberger's (1962) incidence analysis of the corporate tax. In the longer run, however, as Feldstein's (1974) work on variable factor supply indicates, the burden of this tax is increasingly shifted to labor. 
TABLE 8

PATH FOR THE PRICE OF CAPITAL RELATIVE TO THE PRICE OF LABOR, WHEN DISTORTIONARY TAXES ARE REPLACED WITH

LUMP SUM TAXES ${ }^{\mathrm{a}}$

\begin{tabular}{|c|c|c|c|}
\hline \multirow[b]{2}{*}{ Year } & \multicolumn{3}{|c|}{ Relative Price of Capital } \\
\hline & $\begin{array}{c}\text { Myopic } \\
\text { Expectations }\end{array}$ & $\begin{array}{c}10 \text { Years } \\
\text { of Foresight }\end{array}$ & $\begin{array}{c}50 \text { Years } \\
\text { of Foresight }\end{array}$ \\
\hline 1973 & 2.129 & 2.129 & 2.129 \\
\hline 1978 & 1.932 & 1.948 & 1.954 \\
\hline 1983 & 1.793 & 1.815 & 1.824 \\
\hline 1988 & 1.689 & 1.714 & 1.725 \\
\hline 1993 & 1.611 & 1.637 & 1.648 \\
\hline 1998 & 1.551 & 1.575 & 1.587 \\
\hline 2003 & 1.503 & 1.526 & 1.538 \\
\hline 2008 & 1.466 & 1.437 & 1.498 \\
\hline 2013 & 1.435 & 1.455 & 1.465 \\
\hline 2018 & 1.411 & 1.429 & 1.438 \\
\hline 2023 & 1.391 & 1.407 & 1.416 \\
\hline 2028 & 1.375 & 1.389 & 1.397 \\
\hline 2033 & 1.361 & 1.374 & 1.382 \\
\hline 2038 & 1.350 & 1.362 & 1.368 \\
\hline 2043 & 1.341 & 1.351 & 1.357 \\
\hline 2048 & 1.333 & 1.343 & 1.348 \\
\hline 2053 & 1.327 & 1.335 & 1.340 \\
\hline 2058 & 1.322 & 1.329 & 1.334 \\
\hline 2063 & 1.317 & 1.324 & 1.328 \\
\hline 2068 & 1.314 & 1.320 & 1.323 \\
\hline 2073 & 1.311 & 1.316 & 1.319 \\
\hline
\end{tabular}

$a_{\text {Labor }}$ supply elasticity $=0.15$; saving elasticity $=0.4$. Relative price of capital was 1.0 in every period of base case sequence. 
Because of the capital deepening, it is not surprising that a large proportion of the welfare gains occurs in the distant future. Even when we carry out our calculations 100 years, we still find that 16 percent of the welfare gains occur in the termination term. This raises the obvious question of how sensitive these gains would be to changes in the discount rate. In Table 9, we see that the removal of all distortionary taxes leads to substantial welfare gains, even when a six percent real discount rate is used. We do not report dollar figures in Table 9, since the present values of both the base case sequence and the revise case sequence are affected by the discounting.

\section{TABLE 9}

\section{WELFARE GAIN FROM REPLACING THE EXISTING TAX SYSTFM}

WITH A LUMP SUM TAX: SENSITIVITY ANALYSIS

WITH RESPECT TO THE DISCOUNT RATE ${ }^{\mathrm{a}}$

Discount Rate $(\%)$

3

4

5

6
Welfare Gain as a Percentage of Revenue

$28.3 \%$

22.1

18.0

15.0

${ }^{a_{\text {Labor }}}$ supply elasticity $=0.15$; saving elasticity $=0.4$.

In the simulation in which all distortionary taxes are replaced by a lump sum tax, labor supply increases in response to the removal of tax distortions, but the increase is not nearly so large (relatively) as the increase in saving. Of course, this flows directly from our assumptions about factor supply elasticities. Labor supply in the revised sequence is higher than in the base sequence by 18.5 percent in the first period and 15.7 percent 
in the final period. Consumption of goods rises instantaneously by eleven percent. This is possible, despite the large increase in saving, because of the increase in labor supply. In the final period of the revised sequence (i.e., after 100 years), consumption is 33 percent higher than in the base sequence. For most of the 15 consumer goods, the increase is near this 33 percent figure. However, we find large increases in the consumption of the three consumer goods which were heavily taxed. Consumption of alcohol increases by 133 percent, of tobacco by 141 percent, and of gasoline by 69 percent.

Finally, let us look at some of the changes in the industrial composition of output which are brought about by the tax changes. In every period of the base case sequence, the lightly taxed agriculture and real estate industries account for 5.7 percent and 8.2 percent of total output, respectively. In the first period of the revised sequence, these figures drop to 4.8 percent and 6.5 percent, respectively. On the other hand, the heavily taxed metals and machinery industry increases from 12.6 percent to 14.2 percent, and trade grows from 11.5 percent to 11.9 percent of total output. Over time, the decrease in the relative price of capital leads the output proportions part of the way back to their original positions.

In Table 10, we break down the results of Table 6 by calculating the welfare gains associated with removing the major groups of distortionary taxes, using a labor supply elasticity of 0.15 and a saving elasticity of 0.4 . Thus, Table 10 can be compared with Table 5, in the same way in which Table 6 could be compared with Table 4 .

Table 10 indicates that capital taxes at the industry level and income taxes are the most important causes of distortion on average. This is not surprising in view of the fact that growth of the capital stock is important 
TABLE 10

WELFARE GAINS FROM REPLACING DIFFERENT PORTIONS

OF THE TAX SYSTEM WITH LUMP SUI TAXES

(in billions of 1973 dollars) ${ }^{\mathrm{a}}$

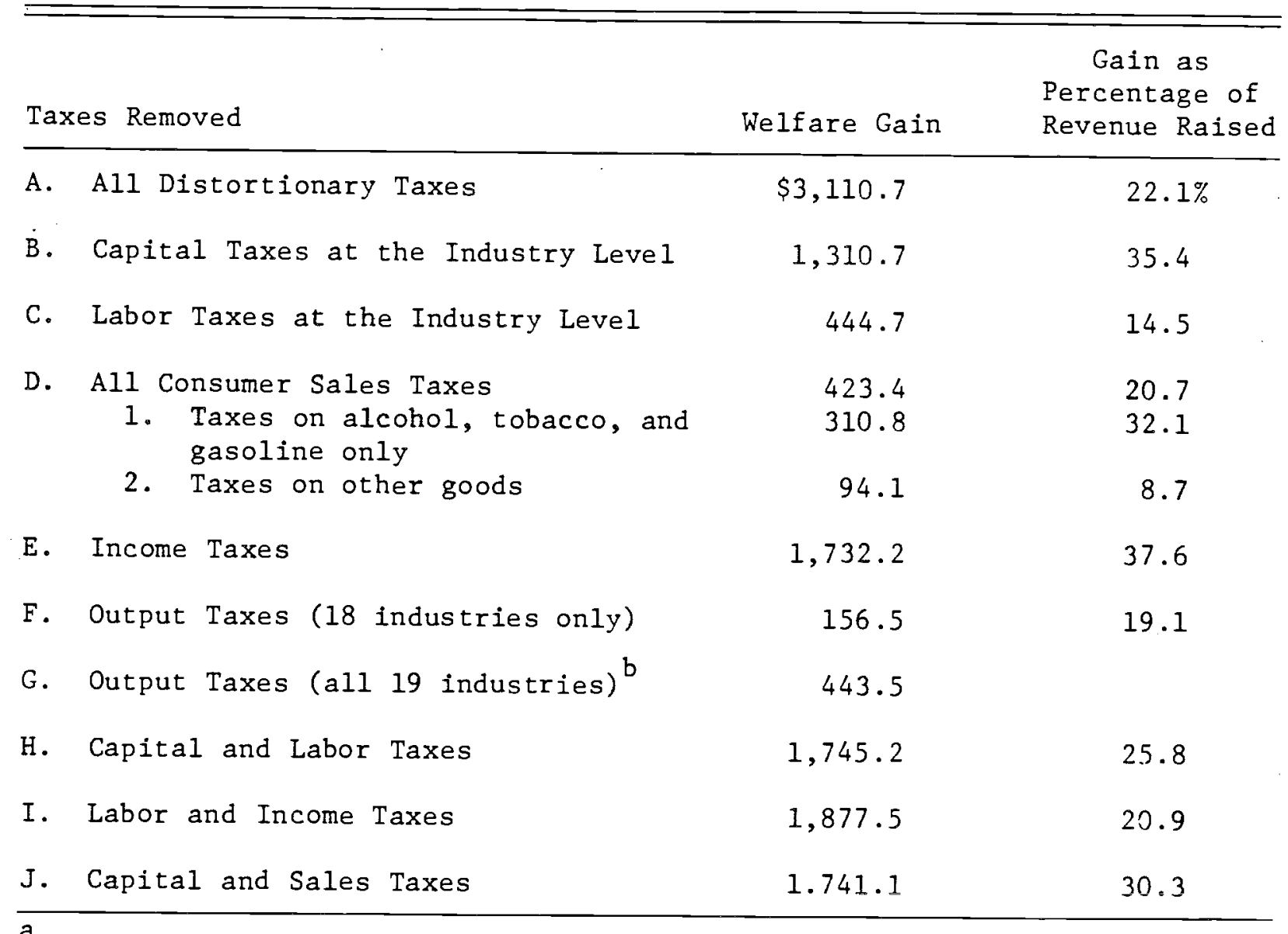

${ }^{a}$ Assuming saving elasticity $=0.4$; labor supply elasticity $=0.15$.

${ }^{b}$ See footnote 9 regarding expressing the gain as a percentage of revenue raised for this simulation.

for long term welfare improvements. Also, as seen in Table 3, these taxes are the ones with the highest rates.

It is interesting to compare Table 10 with Table 5, and see that the relationship between average loss and marginal loss is somewhat uneven. However, marginal losses are always higher, than average losses. The central tendency is for marginal ratès to be about twice as great as average rates, as we would expect from the simple analysis in Section II. Also in Table 10, we 
consider the second-best issue of how the welfare effects of different taxes interact with each other. Rows $H, I$, and $J$ of Table 10 show that, more or less, "additivity" is preserved. For example, the welfare gain from removing capital taxes and labor taxes is nearly equal to the sum of the gains from removing the two types of taxes in separate simulations.

Because lump sum levies are so unlikely ever to be adopted in practice, it is interesting to ask whether a broadly based tax system, with relatively undifferentiated rates, can give similarly large gains. If we replace the existing system of distortionary taxes with a proportional income tax, we get welfare gains of $\$ 1,851.3$ billion in 1973 dollars. This is 13.2 percent of revenues and 60 percent of the gain from removing all taxes and replacing them with lump sum levies. The tax rate which is necessary to raise all of this revenue is around 42 percent. ${ }^{10}$ Broadly speaking, this experiment yields behavior which is similar to that under the lump sum replacement. The capital/labor ratio increases by more than 36 percent, not only because of a large increase in saving, but also because of a small decrease in labor supply. Another alternative for a broadly based tax is a progressive income tax. To simulate such a plan, we keep the same progressive marginal rates that we had in our base sequence, and scale each of them up by the same number of percentage points until all of the required revenue is collected. This plan makes the "equity-efficiency tradeoff" stand out in bold relief. There is still a large welfare gain of $\$ 814.8$ billion, but it is less than half as large as the gain under a proportional income tax. The tax rates necessary to achieve equal revenue yield range from around 18 percent for the lowest income consumer to around 58 percent for the group with the highest incomes. 
A third broadly based tax is a value-added tax (VAT). We simulate replacing the existing distortionary system with a VAT of the consumption type. $^{11}$ As with our other broadly-based alternative tax plans, the VAT leads to substantial capital deepening. The relative price of capital rises at first to 1.842 , as a result of the lowering and equalization of capital tax rates. The added incentives to save eventually lead to a 53 percent increase in the capital/labor ratio, as a result of which the relative price of capital falls to about 1.04 . The value-added tax rate necessary to replace the existing system is in the range of 32 percent of gross sales.

The welfare gain resulting from the move to a VAT is $\$ 2,878.0$ billion in 1973 dollars, or about 20.4 percent of revenues. This is more than 90 percent of the gain which we reported for the lump sum tax. This may seem surprisingly high. The reason for this is that the income effects from the lump sum simulation and the simulations of broadly based alternatives are substantially different. In our model, the upper income groups have the highest propensities to save. Consequently, highly progressive lump sum schemes like the one we have used here will lead to less saving than less progressive schemes. ${ }^{12}$ We therefore ran another simulation, in which the existing tax system is replaced by a set of lump sum taxes allocated according to income in the base case. ${ }^{13}$ The welfare gain associated with this type of lump sum replacement is $\$ 3,721.2$ billion, or 26.4 percent of revenues. In Table 11, we summarize the results from these two lump sum simulations and from the simulations using broadly based distortionary taxes.

In Section II, we suggested that not only the level but also the dispersion of tax rates is important to the welfare cost of taxation. For each major portion of the tax system, we would like to know how much welfare 
TABLE 11

WELFARE GAINS FROM REPLACING THE EXISTING TAX SYSTEM

WITH VARIOUS TYPES OF TAXES

\begin{tabular}{lcc}
\hline \hline $\begin{array}{c}\text { Type of } \\
\text { Replacement Tax }\end{array}$ & $\begin{array}{c}\text { Welfare Gain } \\
\text { (in billions of } \\
1973 \text { dollars) }\end{array}$ & $\begin{array}{c}\text { Gain as } \\
\text { Percentage of } \\
\text { Revenues }\end{array}$ \\
\hline $\begin{array}{l}\text { Lump Sum tax in proportion to } \\
\text { income and sales taxes paid }\end{array}$ & $\$ 3,110.7$ & $22.1 \%$ \\
$\begin{array}{l}\text { Lump Sum tax in proportion to } \\
\text { income }\end{array}$ & $3,721.2$ & 26.4 \\
Proportional Income tax & $1,851.3$ & 13.2 \\
Progressive Income tax & 814.8 & 5.8 \\
Consumption-type Value-added tax & $2,878.0$ & 20.4 \\
\hline
\end{tabular}

loss is due to high taxes, and how much is due to taxes which discriminate among industries, goods, or consumer groups. In the case of taxes on capital at the industry level, this amounts to an analysis of intertemporal distortions versus interindustry distortions.

We already have reported that replacing the taxes on capital at the industry level leads to a welfare improvement of $\$ 1,311$ billion. How much of an improvement would we have if we equalized these rates at the average level existing in the base case? Our estimate is approximately $\$ 448$ billion, or just over one-third of the total. While the distortions across sectors are costly (they outweigh the costs of the distortions from all labor taxes at the industry level), it is clearly the intertemporal distortion which has the greatest effect. This contrasts with Harberger's (1964, p. 30) study, from which he concludes: 
- . the U.S. economy very likely suffers greater costs from tax-induced misallocations of its given capital stock than from the influence of taxation on the overall size of that capital stock.

We believe that the reason for the difference is that the simple Harberger framework could not be adapted easily to the study of the growth of the economy over time.

Intersectoral distortions are relatively more important for consumer purchase taxes. Equalization of consumer purchase tax rates leads to a welfare gain of $\$ 266$ billion, or more than 62 percent of the gain from removing sales taxes entirely. Just the opposite is true of the taxes on labor at the industry level. Equalization of these rates produces a negligible effect. These results are not surprising in light of the data in Table 3 . That table showed that the coefficient of variation of labor taxes is minuscule, while capital tax rates are moderately variable and consumer purchase tax rates are highly variable.

Finally, we can ask what would happen if the rates were equalized within every portion of the tax system (i.e., capital tax rates, income tax rates, etc., are all set to their average values). In this case, we find that the economy would enjoy a welfare gain of $\$ 1,295.8$ billion, or more than 41 percent of the gain from replacing all distortionary taxes with lump sum taxes in proportion to income and sales taxes paid. These results are summarized in Table 12. The implication for tax policy is clear: large welfare gains could accrue if we were to equalize tax rates. 
TABLE 12

WELFARE GAINS FROM EQUALIZING TAX RATES

FOR VARIOUS GROUPS OF TAXES ${ }^{a}$

\begin{tabular}{|c|c|c|}
\hline Type of Tax Equalized & $\begin{array}{l}\text { Welfare Gain } \\
\text { (in billions of } \\
1973 \text { dollars) }\end{array}$ & $\begin{array}{l}\quad \text { Gain as } \\
\quad \text { Percentage of } \\
\text { Gain from Replacing } \\
\text { this Group of Taxes } \\
\text { with Lump Sum Taxes }\end{array}$ \\
\hline Capital Taxes at the Industry Level & $\$ \quad 447.7$ & $34.2 \%$ \\
\hline Consumer Sales Taxes & 266.3 & 62.9 \\
\hline Income Taxes & 601.0 & 34.9 \\
\hline Output Taxes & 30.1 & 6.8 \\
\hline All Groups of Taxes ${ }^{a}$ & $1,295.8$ & 41.7 \\
\hline
\end{tabular}

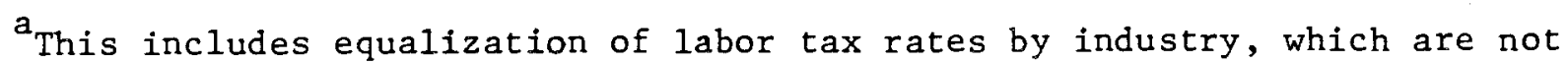
reported separately because the gains from equalization are negligible. 


\section{Conclusion}

Most of the earlier studies using this model have focused on specific policy proposals, such as corporate tax integration or the consumption tax. The present paper is designed to give more general guidance to policy. The central message of this paper is that the welfare losses caused by distortionary taxation can be very large. This is true both on average and at the margin.

The marginal welfare loss to consumers from raising an additional dollar of revenue is in the range of 34 cents to 48 cents. This has very important implications for cost-benefit analysis. Samuelson (1954) developed the condition for the optimal provision of a pure public good, namely, that the sum of the marginal rates of substitution should equal the marginal rate of transformation. However, this condition will only hold if the public expenditure can be covered by lump sum taxes. If a public project must be financed by distortionary taxes which cause deadweight loss, this excess burden must be taken into account when we decide whether to undertake the project. Our calculations indicate that the deadweight loss is between one-third and one-half of revenues. This large wedge could cause us to approve many fewer projects than we would approve if we were to use the simple Samuelson condition.

The average deadweight loss per dollar of revenue is smaller than the marginal deadweight loss, but it is still substantial. We estimate that the gain from replacing the distortionary tax system with certain lump sum taxes would be in the range of 13 cents to 22 cents per dollar. The gains would be about 60 percent as great if the existing system were replaced with a proportional income tax. Replacing the existing system with a consumption-type 
value-added tax would give even greater gains than those from switching to a proportional income tax.

The greatest causes of inefficiency are the heavy taxation of capital at the industry level, and of personal incomes. Each of these leads to substantial intertemporal distortion. The intertemporal distortions appear to be more important than intersectoral distortions, although the latter are quite large. We should note, however, that these results were achieved with data from 1973, when capital taxes were higher than they are now. The tax changes passed in 1981 amounted to a substantial reduction in marginal taxes on corporate capital. These changes will move us in the right direction (see Fullerton and Henderson [1981]). Nevertheless, we believe that there is still a good deal of room for improvement in the efficiency of the tax code. For one thing, we find that equalizing the tax rates across sectors, goods, or consumers for the various parts of the tax system would lead to gains with a present value of almost $\$ 1.3$ trillion, or about nine percent of revenue. Our central conclusion is that considerations of economic efficiency are very important to the evaluation of the tax system. These considerations should be taken into account in two ways. First, we can design a tax system which is more efficient. Secondly, regardless of what tax system we use, we should consider its efficiency properties when we choose the level of public expenditure. 


\section{Footnotes}

1. We will report our results in 1973 dollars, because our model is specified with 1973 data.

2. The lump sum taxes in question were assigned in proportion to income and sales taxes paid by the 12 consumer groups in our model. Different methods of assigning the lump sums lead to different welfare gains. In some cases, these were substantially greater.

3. In both our marginal and average calculations, we find that consumer purchase taxes are highly distortionary. However, these results are determined mainly by the very high taxes on alcohol, tobacco, and gasoline. We urge caution in interpreting these results, for two reasons. First, the taxes on alcohol and tobacco may be viewed as correcting externalities, and the gasoline taxes may be viewed as benefit-related charges. Second, we model consumer purchases with a Cobb-Douglas utility function, which may overstate substantially the own-price elasticities of demand for these goods.

4. Auerbach, Kotlikoff, and Skinner (1982) and Hausman (1981) also find that progressive tax systems perform substantially less well than proportional systems, in terms of overall welfare.

5. The manuipulations which follow can also be found in Browning (1976). Both in this partial equilibrium analysis and in our later general equilibrium calculations, we implicitly ignore certain issues raised by Atkinson and Stern (1974). They analyze two cases under which the economy might want to provide more public goods in the presence of distortionary taxes than in the presence of lump sum taxes. The first is when there is complementarity between public goods and taxed private goods. In our model, we do not consider public production per se. Secondly, Atkinson and Stern consider the case of taxed goods which are inferior. However, our utility functions restrict all goods to be normal.

6. Calculations based on equation (4) but which use tax rates as a proportion of gross expenditure may understate the welfare loss from distortionary taxation. This is one reason why Browning calculates marginal excess burden figures which are lower than ours.

7. These are incomes as defined for the 1973 Consumer Expenditure Survey.

8. Our model exaggerates this effect, since we do not capture life cycle differences among households.

9. A complication is caused by the fact that one of the output tax rates is negative. We model the subsidies to government enterprises as a negative tax on the output of that industry. One procedure would be to multiply all rates by 1.01 except for the subsidy to government enterprises, which we would multiply by 0.99 . This would be an acceptable procedure 
for a simulation of marginal excess burden, but the results would not be comparable with a calculation of the welfare gain from setting all output tax rates to zero. To see this, consider the extreme case in which the net revenue from the subsidy and the various taxes is zero. Then, although the marginal excess burden might have a reasonable value, the welfare gain per dollar of revenue from removing the taxes and subsidy would be infinite. Thus, we report two results for output taxes. In one case, we alter all 19 rates. In the other case, we alter only the rates on outputs other than that of the government enterprises industry.

10. This contrasts with some popular discussions of the "flat tax," in which tax rates of around 20 percent are mentioned. The difference, of course, is that the simulations reported here are concerned with replacing all distortionary taxes, rather than only the Federal taxes.

11. We get the same results, regardless of whether we model an origin-based or destination-based VAT. For an explanation of this equivalence, see Goulder, Shoven, and Whalley (1982).

12. Because of this, and because we do not use an explicit life cycle model, we do not emphasize the distributional results of these simulations.

13. Allocation according to income has been used in some of the earlier papers using this model, e.g., Fullerton, et al., (1981). 


\section{$\underline{\text { References }}$}

Atkinson, A. B., and N. H. Stern. "Pigou, Taxation, and Public Goods." Review of Economic Studies 41, no. 125 (January 1974).

Auerbach, Alan J.; Laurence J. Kotlikoff; and Jonathan Skinner. "The Efficiency Gains from Dynamic Tax Reform." NBER Working Paper No. 819, December, 1981.

Ballard, Charles L., and Lawrence H. Goulder. "Expectations in Numerical General Equilibrium Models." Mimeo, Stanford University, 1982.

Ballard, Charles L.; Don Fullerton; John B. Shoven; and John Whalley. Evaluation of United States Tax Policies with a Numerical General Equilibrium Model. Amsterdam: North-Holland Publishing Company, forthcoming, 1983.

Borjas, George J., and James J. Heckman. "Labor Supply Estimates for Public Policy Evaluation." Proceedings of the Industrial Relations Research Association (1978): 320-31.

Browning, Edgar K. "The Marginal Cost of Public Funds." Journal of Political Economy 84 (April 1976): 283-98.

Denison, Edward F. "A Note on Private Saving." Review of Economic Statistics 40 (August 1958): 261-67.

Feldstein, Martin. "Incidence of a Capital Tax in a Growing Economy with Variable Savings Rates.". Review of Economic Studies 41 (October 1974).

Fullerton, Don, and Yolanda K. Henderson. "Long Run Effects of the Accelerated Cost Recovery System." Discussion Paper No. 20, Woodrow Wilson School, Princeton University, December, 1981.

Fullerton, Don; Yolanda K. Henderson; and John B. Shoven. "A Comparison of Methodologies in Empirical General Equilibrium Models of Taxation." National Bureau of Economic Research Working Paper No. 911, June 1982. Also in H. Scarf and J. B. Shoven (eds.), Applied General Equilibrium Analysis. Cambridge University Press, Eorthcoming, 1983.

Fullerton, Don; A. Thomas King; John B. Shoven; and John Walley. "Corporate Tax Integration in the United States: A General Equilibrium Approach." American Economic Review 71 (September 1981): 677-91.

Fullerton, Don; John B. Shoven; and John thalley. "General Equilibrium Analysis of U.S. Taxation Policy." In Office of Tax Analysis, U.S. Treasury Department, 1978 Compendium of Tax Research. Washington, D.C.: U.S. Government Printing Office, 23-55. 
Goulder, Lawrence; John B. Shoven; and John Whalley. "Domestic Tax Policy and the Foreign Sector: The Importance of Alternative Foreign Policy Formulations to Results from a General Equilibrium Tax Analysis Model." In Martin S. Felstein (ed.), Simulation Methods in Tax Policy Analysis. Chicago: University of Chicago Press, forthcoming, 1982.

Harberger, Arnold C. "The Incidence of the Corporation Income Tax." Journal of Political Economy 70 (June 1962): 215-40.

- "Taxation, Resource Allocation, and Welfare." In.

National Bureau of Economic Research, The Role of Direct and Indirect Taxes in the Federal Revenue System. Princeton, N.J.: Princeton University Press, 1964. Pp. 25-70.

- "Efficiency Effects of Taxes on Income from Capital." In

M. Krzyzaniak (ed.), Effects of Corporation Income Tax. Detroit, Mi.: Wayne State University Press, 1966.

Hausman, Jerry A. "Labor Supply." In Henry J. Aaron and Joseph A. Pechman (eds.), How Taxes Affect Economic Behavior. Washington, D.C.: The Brookings Institution, 1981 .

Killingsworth, Mark R. Labor Supply. New York: Cambridge University Press, forthcoming, 1982 .

Merrill, 0. H. "Applications and Extension of an Algorithm that Computes Fixed Points to Certain Upper Semi-Continuous Point-to-Set Mappings." Unpublished Ph. D. dissertation, University of Michigan, 1972.

Samuelson, Paul A. "The Pure Theory of Public Expenditure." Review of Economics and Statistics 36 (November 1954): 387-89.

Scarf, Herbert E. (wtih collaboration of Terje Hansen). The Computation of Economic Equilibria. New Haven, Conn.: Yale University Press, 1973

Shoven, John B., and John Whalley. "General Equilibrium with Taxes: A Computational Procedure and an Existence Proof." Review of Economic Studies 40 (1973): 475-90.

Starrett, David A. "Long Run Savings Elasticities in the Life Cycle :'ode1." Factor Markets Workshop Research Paper No. 24 , Stanford University, 1982.

Stiglitz, Joseph E. "Taxation, Corporate Financial Policy, and the Cost of Capital." Journal of Public Economics 2, no. 1 (1973): 1-34.

Summers, Lawrence H. "Capital Taxation and Accumulation in a Life Cycle Growth Model." American Fconomic Review 71 (September 1981): 533-44. 